\title{
PRKN wt Allele
}

\author{
National Cancer Institute
}

\section{Source}

National Cancer Institute. PRKN wt Allele. NCI Thesaurus. Code C90312.

Human PRKN wild-type allele is located in the vicinity of $6 q 26$ and is approximately 1380 $\mathrm{kb}$ in length. This allele, which encodes E3 ubiquitin-protein ligase parkin protein, may be involved in the modulation of ubiquitination. Mutation of the gene is associated with Parkinson disease. Somatic mutations may be associated with either ovarian or lung adenocarcinoma. 